\title{
Spatial variability of Regosol chemical attributes in guava management with neem under semi-arid conditions
}

\author{
Douglas B. Castro ${ }^{1}$, Elvira M. R. Pedrosa ${ }^{2}$, Abelardo A. A. Montenegro ${ }^{2}$, \\ Mario M. Rolim², Diego A. H. S. Leitão ${ }^{3} \&$ Ana Karina S. Oliveira ${ }^{3}$ \\ ${ }^{1}$ Universidade Federal Rural de Pernambuco/Programa de Fitopatologia. Recife, PE. E-mail: dougbcastro@gmail.com \\ ${ }^{2}$ Universidade Federal Rural de Pernambuco/Departamento de Engenharia Agrícola. Recife, PE. E-mail: elvira.pedrosa@ufrpe.br; abelardo. \\ montenegro@yahoo.com.br; mario.rolim@ufrpe.br (Corresponding author) \\ ${ }^{3}$ Universidade Federal Rural de Pernambuco/Programa de Engenharia Agrícola. Recife, PE. E-mail: didiarruda@hotmail.com; akmsol22@hotmail.com
}

\section{Key words: \\ Azadirachta indica \\ management \\ soil quality \\ Psidium guajava}

\begin{abstract}
A B S T R A C T
Considering the relevant importance of guava (Psidium guajava) in Northeastern Brazil along with the benefits of neem cake amendments on soil characteristics, this work evaluated the effects of neem cake on chemical attributes of a Regosol under irrigated guava orchard in an alluvial valley of Pernambuco semi-arid region. Evaluations were carried out in two areas (area 1 - with neem cake; area 2 - without neem cake) at three periods: before the first application of neem cake, 90 days after the first application and 90 days after the second application. A regular $8 \times 6$-point grid was designed in each area and the soil was sampled for total organic carbon, $\mathrm{pH}$, soluble salts $\left(\mathrm{Na}^{+}, \mathrm{K}^{+}, \mathrm{Ca}^{2+}\right.$ and $\left.\mathrm{Mg}^{2+}\right)$ and total nitrogen contents, as well as soil C-CO $\mathrm{CO}_{2}$ evolution rate in soil. Geostatistical analysis pointed out the spherical model as the best fit to the studied variables, followed by the Gaussian model, with ranges from 12 to $60.5 \mathrm{~m}$. Neem cake incorporation increased spatial variability and the contents of the evaluated soil chemical attributes.
\end{abstract}

\section{Palavras-chave:}

Azadirachta indica manejo qualidade do solo Psidium guajava

\section{Variabilidade espacial de atributos químicos em Neossolo no manejo da goiabeira com nim no semiárido}

\section{R E S U M O}

Considerando a importância do cultivo de goiabeiras (Psidium guajava) para o nordeste do Brasil e os benefícios da aplicação da torta de nim nas características do solo, avaliou-se o efeito da aplicação de torta de nim nos atributos químicos de um Neossolo Regolítico cultivado com goiabeiras irrigadas no semiárido de Pernambuco. Para as avaliações foram usadas duas áreas (área 1 - com nim; área 2 - sem nim) e três períodos, antes da aplicação do nim, 90 dias após a primeira aplicação e 90 dias após a segunda aplicação; assim, 96 amostras de solo foram coletadas em duas malhas regulares de $8 \times 6$ pontos amostrais e realizadas análises do teor de carbono orgânico total, $\mathrm{pH}$, teores de sais solúveis $\left(\mathrm{Na}^{+}, \mathrm{K}^{+}\right.$,

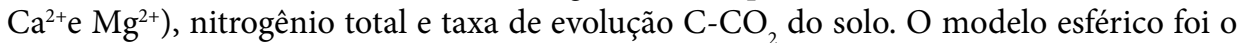
que melhor se ajustou às variáveis estudadas seguido pelo gaussiano, com alcances que variaram de 12 a 60,5 m. A incorporação da torta de nim aumentou a variabilidade espacial e a oferta dos atributos de solo estudados. 


\section{INTRODUCTION}

Guava (Psidium guajava L.) is a rustic fruit crop, with good capacity of dispersion and rapid adaptation to different environments. Guava fruits have excellent acceptance in the market due to the great variety of products, by-products and forms of consumption (Campos et al., 2013). In Brazil, the crop is predominantly grown using family labor, on 3 to 5 ha farms. In the Northeast, the regional production is concentrated in the irrigated districts of Pernambuco and Bahia, due to the water availability, favorable conditions of soil and climate and advanced mechanization techniques (Araújo et al., 2013). With adequate irrigation and phytosanitary management, the orchards may reach yields higher than $40 \mathrm{t} \mathrm{ha}^{-1}$; however, half of this yield has been reported in the country. The concern about the use of agrochemicals, not only for the risks to humans and the environment, but also for the increments in production costs (Soares \& Porto, 2012), has stimulated the search for more sustainable management alternatives, such as the incorporation of neem (Azadirachta indica A. Juss) cake to the soil.

Known as an important medicinal plant since the medieval period, neem has activity against more than 430 species of pests (Martinez, 2002) and is used for pest management due to the low cost and ecological viability; however, despite the effectiveness of neem by-products in the integrated management of pests and diseases (Chaves et al., 2012), there is little information on how these products affect soil chemical quality, particularly under semiarid conditions. This study aimed to evaluate variations in spatial-temporal distributions of soil chemical attributes after the incorporation of neem cake in a guava orchard in the Pernambuco semiarid region.

\section{Material AND Methods}

The experiment was carried out from April to October 2013 in a commercial orchard of 'Paluma' guava, with six months of planting, in a rural settlement in the Ipanema River sub-basin, in the municipality of Pesqueira-PE, Brazil. The experimental area has 0.84 ha and is situated between the coordinates of $8^{\circ} 23.835^{\prime}$ and $8^{\circ} 23.903^{\prime} S$ and $36^{\circ} 51.515^{\prime}$ and $36^{\circ} 51.475^{\prime}$ $\mathrm{W}$, with south-north slope of $0.4 \%$. The soil in the area was predominantly described as Fluvent Entisol, with 751.32, 169.13 and $79.55 \mathrm{~g} \mathrm{~kg}^{-1}$ of sand, silt and clay, respectively. The climate in the region, according to Köppen's classification, is BSh (extremely hot, semiarid). Mean annual temperature is $23^{\circ} \mathrm{C}$, mean annual rainfall is $700 \mathrm{~mm}$ and mean annual evapotranspiration is $2000 \mathrm{~mm}$ (Santos et al., 2012).

The orchard was planted by the farmer between the months of September and October 2012. The experimental area was divided into two areas of equal size, Area 1 and Area 2, and the sampling grids were designed according to the position of the plants, alternately along the $\mathrm{X}$ and $\mathrm{Y}$ axes, totaling $48(8 \times 6)$ points per area, each one with approximately 200 plants.

Area 1 was randomly drawn to be amended with the neem cake applied in guava plants according to the sampling grid points each application soil pits were open around the plant, following the canopy projection area, with depth of approximately $25 \mathrm{~cm}$, and the product was uniformly amended at the dose of $1 \mathrm{~kg}$ plant ${ }^{-1}$ and, then, soil pits were filled with soil. The neem cake was provided by the Cruangi Mill and showed contents of 23.92, 14.335, 0.569, 0.966, 1.145, 1.049, 0.512 and $1.041 \mathrm{~g} \mathrm{~kg}^{-1}$ of $\mathrm{N}, \mathrm{K}^{+}, \mathrm{Na}^{+}, \mathrm{Ca}^{2+}, \mathrm{Mg}^{2+}, \mathrm{Zn}^{2+}, \mathrm{Cu}^{+}$and $\mathrm{Mn}^{2+}$, respectively.

Along the experimental period, the orchard was dripirrigated according to the need and did not receive any type of chemical fertilizer. The control of invasive plants was manually performed, without the application of commercial herbicides.

Approximately $2 \mathrm{~kg}$ of soil were sampled from each grid point, at the beginning of the study (s1); 90 days after the first sampling (s2) and 90 days after the second sampling (s3), totaling 180 experimental days. Neem cake was immediately amended after the first (s1) and second (s2) samplings, after which the samples were placed in plastic bags, protected from heat sources, identified and taken to the Laboratory of Soil Chemistry of the Federal Rural University of Pernambuco for chemical analyses of total organic carbon (OC), $\mathrm{pH}$, soluble salts $\left(\mathrm{Na}^{+}, \mathrm{K}^{+}, \mathrm{Ca}^{2+}\right.$ and $\left.\mathrm{Mg}^{2+}\right)$, total nitrogen (TN) and $\mathrm{C}-\mathrm{CO}_{2}$ evolution rate of the soil.

OC was determined through oxidation of organic matter using the wet method; soil $\mathrm{pH}$ was determined using $10 \mathrm{~g}$ of air-dried sieved soil (ADSS) in water (1:2.5); soil contents of soluble $\mathrm{K}^{+}, \mathrm{Na}^{+}, \mathrm{Ca}^{2+}$ and $\mathrm{Mg}^{2+}$ were based on the respective saturation extracts using an atomic absorption spectrophotometer with flame for the reading of divalent cations and a flame photometer for the reading of monovalent cations. Soil TN was quantified from $0.5 \mathrm{~g}$ of ADSS and N reading (dag $\mathrm{kg}^{-1}$ ) performed through titration with diluted $\mathrm{HCl}$, all according to EMBRAPA (2009).

For determination of soil C-CO $\mathrm{CO}_{2}$ evolution rate, $100 \mathrm{~g}$ soil samples were placed in plastic containers at the moment of the samplings and immediately taken to the laboratory, placed along with another container with $10 \mathrm{~mL}$ of $0.5 \mathrm{~N}$ $\mathrm{KOH}$ in a sealed glass chamber for 15 days at $25 \pm 2{ }^{\circ} \mathrm{C}$ in an environment protected from the light. The $\mathrm{CO}_{2}$ absorbed by $\mathrm{KOH}$ was determined through titration with $0.1 \mathrm{~N} \mathrm{HCl}$, using phenolphthalein and methyl orange as indicators.

Data were evaluated through analysis of variance and descriptive statistical analyses, with values of maximum, minimum, mean, median, coefficient of variation, standard deviation and kurtosis, and normality tested by the KolmogorovSmirnov analysis.

The variability of the analyzed attributes was classified according to Warrick \& Nielsen (1980), as low (CV < 12\%), moderate $(12 \%<\mathrm{CV}>24 \%)$ or high $(\mathrm{CV}>24 \%)$. Spatial dependence was analyzed through the fit of the classic semivariogram based on the estimate of the semivariances using the program GEO-EAS. The data were fitted to experimental semivariograms and, subsequently, spherical, Gaussian and exponential models were tested. The mathematical fit enabled the definition of the nugget effect $\left(\mathrm{C}_{0}\right)$, spatial range $(\mathrm{A})$ and sill $\left(\mathrm{C}_{0}+\mathrm{C} 1\right)$.

The fitted models were subjected to cross-validation and the degree of spatial dependence was evaluated based on the classification proposed by Cambardella et al. (1994). Values of the relationship between the nugget effect and the sill of their fitted 
semivariogram lower than $25 \%$ characterize strong dependence; between 25 and 75\%, moderate dependence; and above $75 \%$, weak dependence. The parameters of the semivariance function after fitting to the theoretical models were used in the construction of isoline maps through kriging, in order to define zones of similar variability and divide the area into more homogeneous sub-regions. Isoline maps were constructed using the program Surfer 9.9.785 (Golden Software).

\section{RESUlTS AND Discussion}

When little close, the values of mean and median may indicate non-normality of the data, since they characterize an asymmetric distribution. From the 48 probable combinations for the eight chemical variables analyzed (two areas and three samplings), 23 combinations did not present normal distribution, by KolmogorovSmirnov at 0.05 probability level (Table 1). Based on the CV

Table 1. Descriptive summary of soil chemical attributes in two areas, with (Area 1) and without (Area 2) the addition of neem cake, in guava orchard before the application (Sampling 1), 90 days after the first application (Sampling 2) and 90 days after the second application (Sampling 3)

\begin{tabular}{|c|c|c|c|c|c|c|c|c|}
\hline & Maximum & Minimum & Mean & Median & Kurtosis & CV (\%) & SD & $\overline{\mathrm{KS}}$ \\
\hline & \multicolumn{8}{|c|}{ Area 1 - Sampling 1} \\
\hline $\mathrm{K}^{+}$ & 2.6010 & 0.3597 & 0.9829 & 0.8741 & 1.4168 & 49.0461 & 0.4820 & * \\
\hline $\mathrm{Na}^{+}$ & 9.5256 & 1.6421 & 4.0050 & 3.7572 & 0.9805 & 46.1420 & 1.8480 & * \\
\hline $\mathrm{Mg}^{2+}$ & 3.7029 & 0.1152 & 1.8455 & 1.8308 & -1.0417 & 52.9894 & 0.9779 & * \\
\hline $\mathrm{Ca}^{2+}$ & 5.3771 & 0.6253 & 2.9078 & 2.9863 & 0.4836 & 34.4821 & 1.0026 & * \\
\hline $\mathrm{C}-\mathrm{CO}_{2}$ & 28.546 & 0.1805 & 10.678 & 9.0206 & -0.4198 & 74.8757 & 7.9952 & ns \\
\hline $\mathrm{OC}$ & 0.9400 & 0.0947 & 0.4580 & 0.4453 & 0.0803 & 37.2987 & 0.1708 & $\star$ \\
\hline TN & 0.8386 & 0.3909 & 0.6139 & 0.6156 & -0.3287 & 16.7827 & 0.1030 & ns \\
\hline \multirow[t]{2}{*}{$\mathrm{pH}$} & 8.66 & 5.66 & 7.2158 & 7.19 & 0.3218 & 8.2306 & 0.5939 & * \\
\hline & \multicolumn{8}{|c|}{ Area 1 - Sampling 2} \\
\hline $\mathrm{K}^{+}$ & 1.4640 & 0.5001 & 0.9042 & 0.8730 & -0.2315 & 24.8189 & 0.2244 & * \\
\hline $\mathrm{Na}^{+}$ & 4.2855 & 1.2622 & 2.2919 & 2.1293 & 0.1621 & 36.5822 & 0.8384 & ns \\
\hline $\mathrm{Mg}^{2+}$ & 6.6455 & 0.2468 & 2.5101 & 1.6161 & -0.5374 & 77.4354 & 1.9437 & ns \\
\hline $\mathrm{Ca}^{2+}$ & 5.3196 & 0.1257 & 1.6592 & 1.1916 & 0.7209 & 81.3098 & 1.3491 & ns \\
\hline $\mathrm{C}-\mathrm{CO}_{2}$ & 55.8352 & 1.7018 & 12.810 & 8.2934 & 4.1743 & 89.9790 & 11.527 & ns \\
\hline $\mathrm{OC}$ & 0.9602 & 0.5782 & 0.7327 & 0.7259 & -0.0382 & 12.4799 & 0.0914 & $\star$ \\
\hline TN & 9.5067 & 3.9129 & 6.2283 & 6.1556 & 1.3007 & 17.7099 & 1.1030 & ns \\
\hline \multirow[t]{2}{*}{$\mathrm{pH}$} & 7.1800 & 5.22 & 6.1739 & 6.14 & -0.2549 & 7.8679 & 0.4857 & * \\
\hline & \multicolumn{8}{|c|}{ Area 1 - Sampling 3} \\
\hline $\mathrm{K}^{+}$ & 3.0679 & 0.3034 & 1.2442 & 1.1218 & 0.3894 & 53.3002 & 0.6631 & ns \\
\hline $\mathrm{Na}^{+}$ & 43.5789 & 4.2821 & 15.015 & 9.7589 & -0.0208 & 67.3286 & 10.11 & ns \\
\hline $\mathrm{Mg}^{2+}$ & 5.9046 & 1.4749 & 3.4398 & 3.2974 & -0.2030 & 29.2292 & 1.0054 & * \\
\hline $\mathrm{Ca}^{2+}$ & 5.8026 & 1.5270 & 3.1327 & 3.0699 & 0.2018 & 30.8336 & 0.9659 & * \\
\hline $\mathrm{C}-\mathrm{CO}_{2}$ & 59.3106 & 0.3837 & 19.012 & 16.0067 & 2.6708 & 66.2389 & 12.5934 & ns \\
\hline $\mathrm{OC}$ & 1.2181 & 0.5378 & 0.8766 & 0.8617 & 0.6648 & 15.6121 & 0.1368 & * \\
\hline TN & 12.0995 & 3.7258 & 7.7379 & 7.6479 & 0.3239 & 22.6686 & 1.7540 & ns \\
\hline \multirow[t]{2}{*}{$\mathrm{pH}$} & 7.9800 & 6.2 & 7.2335 & 7.33 & -0.5253 & 6.62554 & 0.4792 & ns \\
\hline & \multicolumn{8}{|c|}{ Area 2 - Sampling 1} \\
\hline $\mathrm{K}^{+}$ & 2.0953 & 0.2863 & 1.0074 & 0.9108 & -0.0733 & 48.0791 & 0.4843 & ns \\
\hline $\mathrm{Na}^{+}$ & 7.9874 & 1.6867 & 3.6232 & 3.1804 & 0.7011 & 45.8461 & 1.6611 & ns \\
\hline $\mathrm{Mg}^{2+}$ & 5.2768 & 0.0494 & 1.8364 & 1.6679 & 0.4484 & 62.8046 & 1.1533 & * \\
\hline $\mathrm{Ca}^{2+}$ & 3.7297 & 0.2318 & 1.7497 & 1.6302 & 0.0518 & 45.2120 & 0.7910 & * \\
\hline $\mathrm{C}-\mathrm{CO}_{2}$ & 101.4208 & 0.1780 & 17.212 & 11.3681 & 8.7955 & 108.2078 & 18.6244 & ns \\
\hline $\mathrm{OC}$ & 0.8270 & 0.0314 & 0.3850 & 0.4091 & -0.164 & 45.2369 & 0.1741 & * \\
\hline TN & 0.7838 & 0.3912 & 0.5652 & 0.5592 & -0.3933 & 17.0447 & 0.0963 & * \\
\hline \multirow[t]{2}{*}{$\mathrm{pH}$} & 7.77 & 6.57 & 7.1620 & 7.21 & -0.0243 & 3.9122 & 0.2801 & * \\
\hline & \multicolumn{8}{|c|}{ Area 2 - Sampling 2} \\
\hline $\mathrm{K}^{+}$ & 2.6373 & 0.3374 & 1.1322 & 1.0452 & 1.4507 & 42.9599 & 0.4864 & * \\
\hline $\mathrm{Na}^{+}$ & 5.1527 & 1.2622 & 2.4301 & 2.0054 & 0.0528 & 45.2244 & 1.0990 & ns \\
\hline $\mathrm{Mg}^{2+}$ & 15.9441 & 0.5299 & 3.5143 & 2.3566 & 4.3123 & 88.7554 & 3.1191 & ns \\
\hline $\mathrm{Ca}^{2+}$ & 23.9859 & 0.1057 & 3.0381 & 1.7645 & 19.954 & 124.6167 & 3.7860 & ns \\
\hline $\mathrm{C}-\mathrm{CO}_{2}$ & 61.6645 & 1.6527 & 16.251 & 11.9606 & 5.2632 & 75.0539 & 12.1967 & ns \\
\hline $\mathrm{OC}$ & 0.9193 & 0.3712 & 0.6498 & 0.666 & 0.3433 & 27.3598 & 0.1128 & * \\
\hline TN & 6.7200 & 4.4692 & 5.3267 & 5.3132 & -0.1455 & 10.1773 & 0.5421 & ns \\
\hline \multirow[t]{2}{*}{$\mathrm{pH}$} & 7.2100 & 5.01 & 6.2191 & 6.4 & 0.0145 & 7.6054 & 0.4808 & * \\
\hline & \multicolumn{8}{|c|}{ Area 2 - Sampling 3} \\
\hline $\mathrm{K}^{+}$ & 2.9935 & 0.3530 & 1.3007 & 0.9978 & -0.4236 & 60.0712 & 0.7813 & ns \\
\hline $\mathrm{Na}^{+}$ & 44.2309 & 4.4125 & 16.462 & 9.6285 & -0.4871 & 72.0765 & 11.8649 & ns \\
\hline $\mathrm{Mg}^{2+}$ & 6.9404 & 1.6539 & 3.6254 & 3.6188 & 0.3515 & 32.4614 & 1.1768 & ns \\
\hline $\mathrm{Ca}^{2+}$ & 8.3756 & 1.9441 & 5.2473 & 5.3425 & 0.0628 & 27.0470 & 1.4192 & * \\
\hline $\mathrm{C}-\mathrm{CO}_{2}$ & 80.0943 & 5.4827 & 20.575 & 15.835 & 5.6447 & 73.0709 & 15.0345 & ns \\
\hline $\mathrm{OC}$ & 1.0586 & 0.4363 & 0.6968 & 0.6626 & -0.4368 & 32.2322 & 0.1549 & * \\
\hline TN & 9.4953 & 3.1695 & 5.8305 & 5.9554 & 0.2254 & 23.6288 & 1.3777 & ns \\
\hline $\mathrm{pH}$ & 8.2200 & 6.75 & 7.5685 & 7.625 & 0.4287 & 4.2053 & 0.3182 & * \\
\hline
\end{tabular}

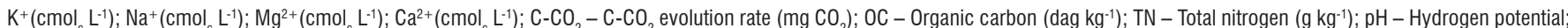
$\mathrm{CV}$ - Coefficient of variation; SD - Standard deviation; $\mathrm{KS}$ - Kolmogorov-Smirnov normality test at 0.05 probability level; ns - Not significant; *Significant 
limits proposed by Warrick \& Nielsen (1980), only pH showed low variability in both areas and in all sampling periods (Table 1). TN showed moderate variability and OC, moderate to strong; the other chemical variables showed high variability $(\mathrm{CV}>24 \%)$, corroborating with Leão et al. (2011).

In Area 1 (Table 1), the variation in the OC contents decreased over time, from a CV of $37.3 \%$, before neem application, to $12.5 \%$ at 90 days after the first application (sampling 2) and $15.6 \%$ at 90 days after the second application (sampling 3), indicating that the uniform application of neem cake in that area may have reduced OC variability, although this reduction in variability also occurred over time in the Area 2, but at lower proportions.

The best fits for the soil attributes (Table 2) were obtained with the spherical model; seven out of eight analyzed soil

Table 2. Parameters of the theoretical semivariograms, degree of spatial dependence and cross-validation of chemical variables of a Regolithic Neosol in two areas, with (Area 1) and without (Area 2) the addition of neem cake, in guava orchard before application (Sampling 1), 90 days after application (Sampling 2) and 90 days after the second application (Sampling 3)

\begin{tabular}{|c|c|c|c|c|c|c|c|c|c|}
\hline & \multirow{2}{*}{ Model } & \multirow{2}{*}{$\mathbf{C}_{0}$} & \multirow{2}{*}{$\mathbf{C}_{1}$} & \multirow{2}{*}{ A } & \multirow{2}{*}{$\mathbf{R}^{2}$} & \multirow{2}{*}{$C_{0} /\left(C_{0}+C 1\right)$} & \multirow{2}{*}{ DSD } & \multicolumn{2}{|c|}{ Jack-Knifing } \\
\hline & & & & & & & & Mean & SD \\
\hline \multicolumn{10}{|c|}{ Sampling 1 - Area 1} \\
\hline $\mathrm{K}^{+}$ & Pure nugg & & & & & & & & \\
\hline $\mathrm{Na}^{+}$ & Exp. & 2.0043 & 1.7263 & 16.7632 & 0.5423 & 53.73 & Mod. & -0.019 & 0.934 \\
\hline $\mathrm{Mg}^{2+}$ & Gauss. & 0.5948 & 0.4968 & 26.2622 & 0.8785 & 54.49 & Mod. & 0.009 & 1.013 \\
\hline $\mathrm{Ca}^{2+}$ & Gauss. & 0.5678 & 0.6742 & 31.3567 & 0.9339 & 45.72 & Mod. & -0.004 & 1.084 \\
\hline $\mathrm{C}-\mathrm{CO}_{2}$ & Gauss. & 0.0917 & 0.0277 & 20.8691 & 0.6381 & 76.80 & Weak & -0.050 & 0.947 \\
\hline $\mathrm{OC}$ & \multicolumn{9}{|c|}{ Pure nugget effect } \\
\hline TN & Gauss. & 0.0074 & 0.0097 & 60.4925 & 0.973 & 43.27 & Mod. & 0.007 & 1.018 \\
\hline $\mathrm{pH}$ & \multicolumn{9}{|c|}{ Pure nugget effect } \\
\hline \multicolumn{10}{|c|}{ Sampling 1 - Area 2} \\
\hline $\mathrm{K}^{+}$ & \multicolumn{9}{|c|}{ Pure nugget effect } \\
\hline $\mathrm{Na}^{+}$ & Spher. & 0.0025 & 0.0160 & 16.19370 & 0.9074 & 13.51 & Strong & 0.026 & 1.070 \\
\hline $\mathrm{Mg}^{2+}$ & Spher. & 0.5673 & 0.7792 & 18.0059 & 0.8857 & 42.13 & Mod. & -0.010 & 1.006 \\
\hline $\mathrm{Ca}^{2+}$ & Spher. & 0.3643 & 0.2731 & 24.4869 & 0.5910 & 57.15 & Mod. & -0.023 & 1.013 \\
\hline $\mathrm{C}-\mathrm{CO}_{2}$ & \multicolumn{9}{|c|}{ Pure nugget effect } \\
\hline OC & \multicolumn{9}{|c|}{ Pure nugget effect } \\
\hline TN & Spher. & 0.0072 & 0.0018 & 38.0168 & 0.8840 & 80.00 & Weak & -0.003 & 1.035 \\
\hline $\mathrm{pH}$ & \multicolumn{9}{|c|}{ Pure nugget effect } \\
\hline & & & & Sampli & - Area 1 & & & & \\
\hline $\mathrm{K}^{+}$ & Pure nugg & & & & & & & & \\
\hline $\mathrm{Na}^{+}$ & Pure nugg & & & & & & & & \\
\hline $\mathrm{Mg}^{2+}$ & Spher. & 2.2362 & 2.1406 & 58.4262 & 0.9855 & 59.43 & Mod. & -0.040 & 1.004 \\
\hline $\mathrm{Ca}^{2+}$ & Gauss. & 1.1948 & 0.8026 & 39.3440 & 0.9249 & 59.43 & Mod. & -0.043 & 0.949 \\
\hline $\mathrm{C}-\mathrm{CO}_{2}$ & Spher. & 89.0934 & 60.8257 & 38.7603 & 0.8757 & 59.43 & Mod. & 0.001 & 1.149 \\
\hline $\mathrm{OC}$ & Spher. & 0.0064 & 0.0026 & 54.6216 & 0.9206 & 71.11 & Mod. & -0.033 & 1.064 \\
\hline TN & Spher. & 0.9679 & 0.1534 & 51.4044 & 0.8001 & 86.32 & Weak & -0.066 & 1.087 \\
\hline $\mathrm{pH}$ & Spher. & 0.0203 & 0.1964 & 16.9613 & 0.6672 & 9.37 & Strong & -0.031 & 1.050 \\
\hline & & & & Sampli & - Area 2 & & & & \\
\hline $\mathrm{K}^{+}$ & Spher. & 0.0644 & 0.0973 & 53.1051 & 0.8416 & 39.83 & Mod. & 0.027 & 1.048 \\
\hline $\mathrm{Na}^{+}$ & Spher. & 0.0154 & 0.0212 & 34.3375 & 0.6986 & 42.08 & Mod. & 0.005 & 1.030 \\
\hline $\mathrm{Mg}^{2+}$ & Spher. & 0.0259 & 0.0495 & 36.6484 & 0.9526 & 34.35 & Mod. & 0.003 & 1.076 \\
\hline $\mathrm{Ca}^{2+}$ & Gauss. & 1.4398 & 2.0341 & 23.3399 & 0.8892 & 41.45 & Mod. & -0.019 & 0.901 \\
\hline $\mathrm{C}-\mathrm{CO}_{2}$ & Gauss. & 82.6639 & 119.177 & 42.8046 & 0.9807 & 40.95 & Mod. & -0.018 & 1.076 \\
\hline $\mathrm{OC}$ & Spher. & 0.0030 & 0.0103 & 27.9968 & 0.9688 & 22.56 & Strong & -0.015 & 1.029 \\
\hline TN & Spher. & 0.1438 & 0.1567 & 18.4857 & 0.7283 & 47.85 & Mod. & -0.002 & 1.058 \\
\hline $\mathrm{pH}$ & Pure nugg & & & & & & & & \\
\hline & & & & Sampli & - Area 1 & & & & \\
\hline $\mathrm{K}^{+}$ & Pure nugg & & & & & & & & \\
\hline $\mathrm{Na}^{+}$ & Pure nugg & & & & & & & & \\
\hline $\mathrm{Mg}^{2+}$ & Spher. & 0.5376 & 0.5234 & 27.4973 & 0.9016 & 50.67 & Mod. & -0.008 & 1.008 \\
\hline $\mathrm{Ca}^{2+}$ & Exp. & 0.5312 & 0.4202 & 12.0180 & 0.7827 & 55.83 & Mod. & -0.051 & 0.908 \\
\hline $\mathrm{C}-\mathrm{CO}_{2}$ & Pure nugg & & & & & & & & \\
\hline $\mathrm{OC}$ & Spher. & 0.0148 & 0.0237 & 17.159 & 0.6654 & 38.44 & Mod. & -0.039 & 1.075 \\
\hline TN & Spher. & 2.2807 & 0.7199 & 29.0486 & 0.7319 & 76.01 & Weak & -0.023 & 1.082 \\
\hline $\mathrm{pH}$ & Pure nugg & & & & & & & & \\
\hline & & & & Sampli & - Area 2 & & & & \\
\hline $\mathrm{K}^{+}$ & Pure nugg & & & & & & & & \\
\hline $\mathrm{Na}^{+}$ & Spher. & 94.5951 & 48.8706 & 32.4872 & 0.9861 & 65.94 & Mod. & -0.013 & 1.106 \\
\hline $\mathrm{Mg}^{2+}$ & Spher. & 0.0200 & 1.3431 & 18.6182 & 0.9428 & 1.47 & Strong & -0.023 & 1.059 \\
\hline $\mathrm{Ca}^{2+}$ & Pure nugg & & & & & & & & \\
\hline $\mathrm{C}-\mathrm{CO}_{2}$ & Spher. & 65.1699 & 149.783 & 21.4709 & 0.6508 & 30.32 & Mod. & 0.019 & 1.246 \\
\hline $\mathrm{OC}$ & Pure nugg & & & & & & & & \\
\hline TN & Pure nugg & & & & & & & & \\
\hline $\mathrm{pH}$ & Pure nugg & & & & & & & & \\
\hline
\end{tabular}

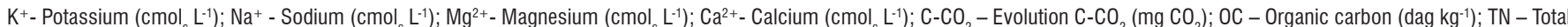
nitrogen $\left(\mathrm{g} \mathrm{kg}^{-1}\right) ; \mathrm{pH}$ - Hydrogen potential; $\mathrm{C}_{0}$ - Nugget effect; $\mathrm{C}_{1}$ - Contribution; $\mathrm{C}_{0}+\mathrm{C}_{1}-$ Sill; $\mathrm{R}^{2}$ - Coefficient of determination; DSD - Degree of spatial dependence; SD - Standard deviation; Spher. - Spherical; Gauss. - Gaussian; Exp. - exponential 
attributes showed nugget effect in at least one of the areas and one of the samplings, except for $\mathrm{Mg}^{2+}$, which were fitted to the spherical or Gaussian models for all areas and sampling periods. The nugget effect is an important measurement of the semivariogram and indicates unexplained variability, which may be due to measurement errors or even undetected microvariation, considering the sampling distance used (Carrasco, 2010).

The ranges obtained for soil chemical attributes (Table 2) showed wide variation with minimum of $12.02 \mathrm{~m}$ for $\mathrm{Ca}^{2+}$ in the third sampling of Area 1 and maximum of $60.49 \mathrm{~m}$ for TN in the first sampling of Area 1. High range values characterize higher continuity in the distribution of the variable, possibly due to the management (Souza et al., 2004).

The isoline maps for the chemical variables that showed spatial dependence in Area 1 are shown in Figure 1. The spatial distributions of $\mathrm{Ca}^{2+}, \mathrm{Mg}^{2+}, \mathrm{TN}, \mathrm{Na}^{+}$and $\mathrm{pH}$ in the first sampling (Figure 1-C1) showed higher levels in the northeast region of the area and lower levels in the central region; coincident regions for these attributes are explained by the greater availability of these ions in the solution of soils with higher $\mathrm{pH}$ (Natale et al., 2012).

At 90 days (sampling 2), the pattern of spatial distribution for $\mathrm{Ca}^{2+}$ and $\mathrm{Mg}^{2+}$ still showed central region with the
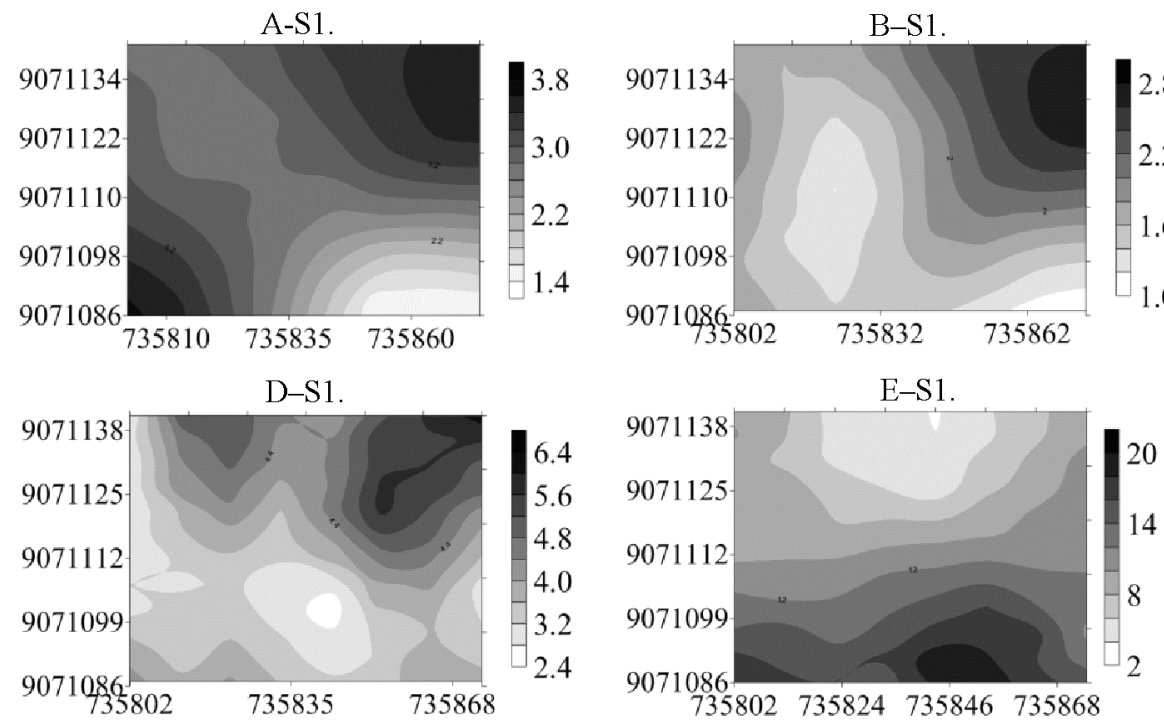

$\mathrm{B}-\mathrm{S} 2$.

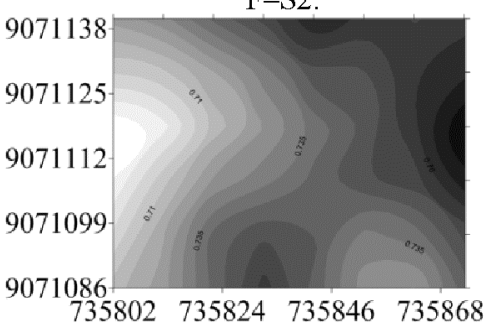

$\mathrm{G}-\mathrm{S} 2$.

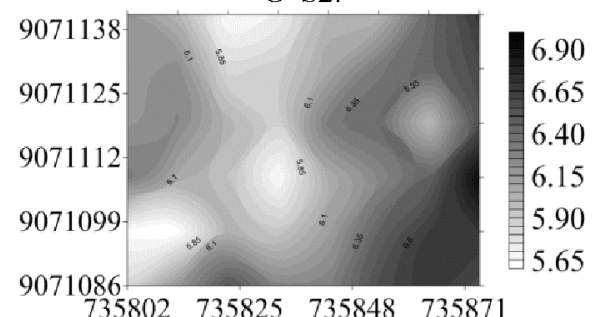

F-S3.

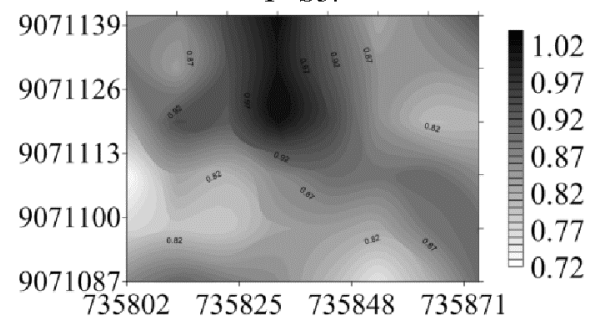

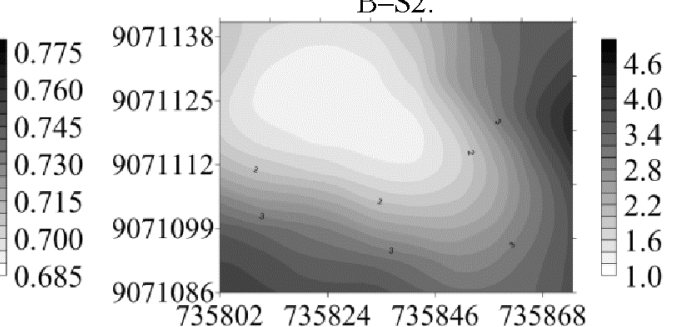

E-S2.

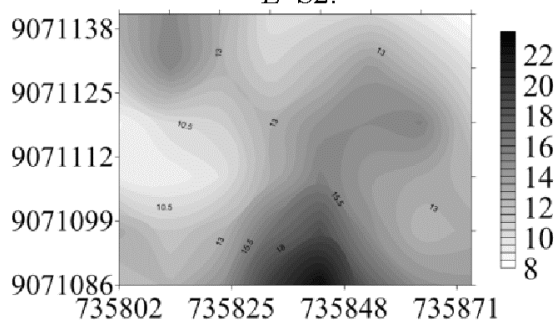

B-S3.

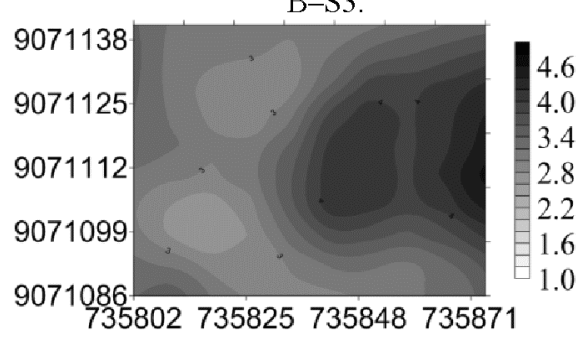

$\mathrm{C}-\mathrm{S} 1$.

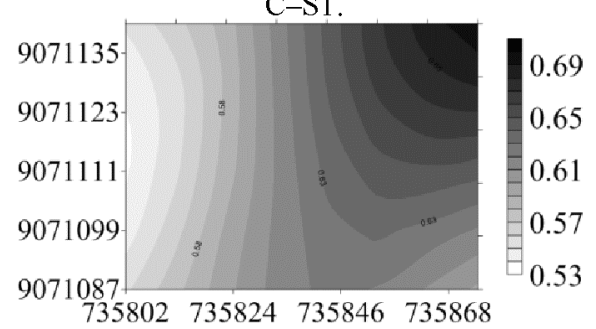

A-S2.

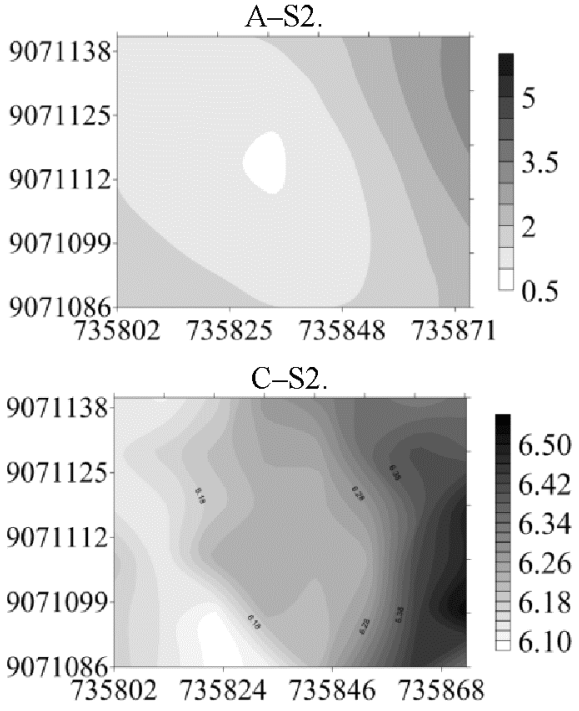

A-S3.

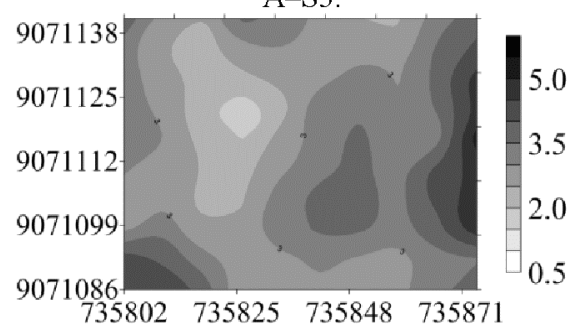

$\mathrm{C}-\mathrm{S} 3$.

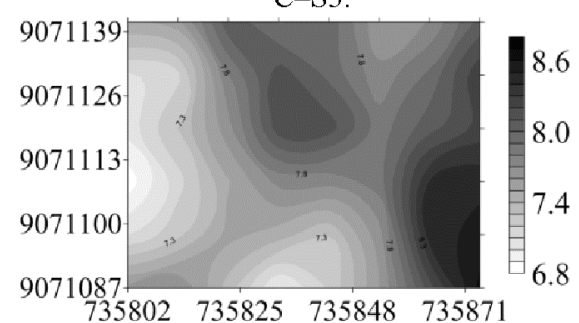

Figure 1. Isoline maps of Area 1 for the contents of calcium (A), magnesium (B), total nitrogen (C), sodium (D), C-CO, evolution rate $(\mathrm{E})$, organic carbon $(\mathrm{F})$ and $\mathrm{pH}(\mathrm{G})$ at six months, before the application of neem cake (S1) and after 90 (S2) and 180 (S3) days 
lowest levels of these nutrients (Figures $1 \mathrm{~A}-\mathrm{C} 1$ and $1 \mathrm{~B}-\mathrm{C} 2$ ), such as in sampling 1 (Figures $1 \mathrm{~A}-\mathrm{C} 1$ and $1 \mathrm{~B}-\mathrm{C} 1$ ). This demonstrates that, at first, the incorporation of neem cake did not interfere with the spatial distribution of these nutrients; the spatial distributions of $\mathrm{OC}$ and TN (Figures $1 \mathrm{~F}-\mathrm{C} 1$ and 1C-C1) indicate higher concentrations on the east region, demonstrating that a great part of soil $\mathrm{N}$ was immobilized in the organic form. Comparing the maps of TN for sampling 1 (Figure 1C-C1) and sampling 2 (Figure 1C-C2), higher values were concentrated in the east region of the area, indicating that, at 90 days, the neem cake did not interfere with the spatial distribution of TN.
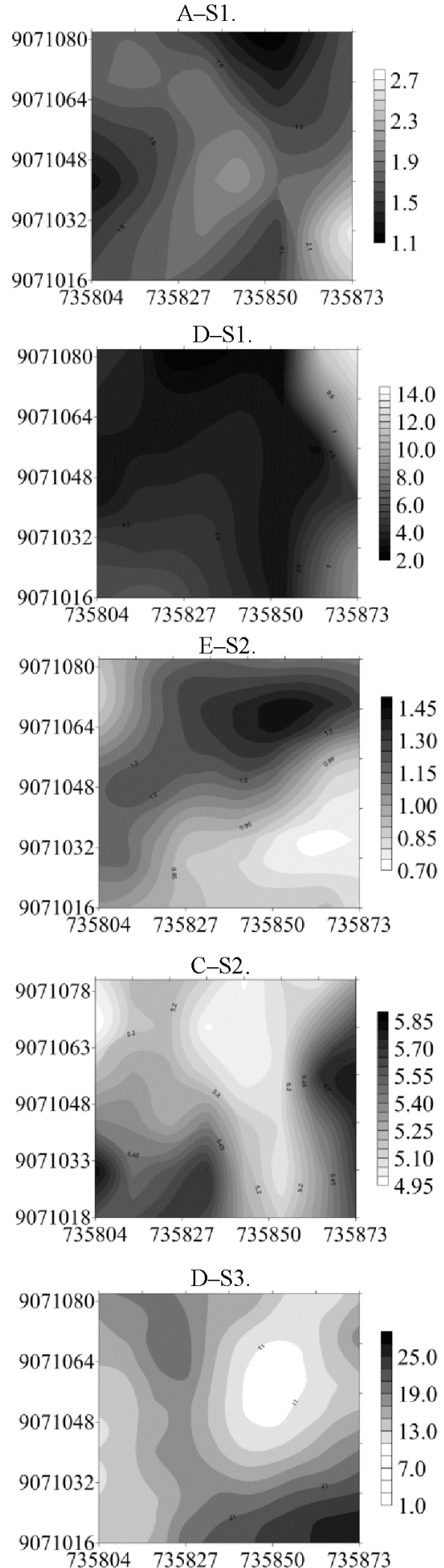
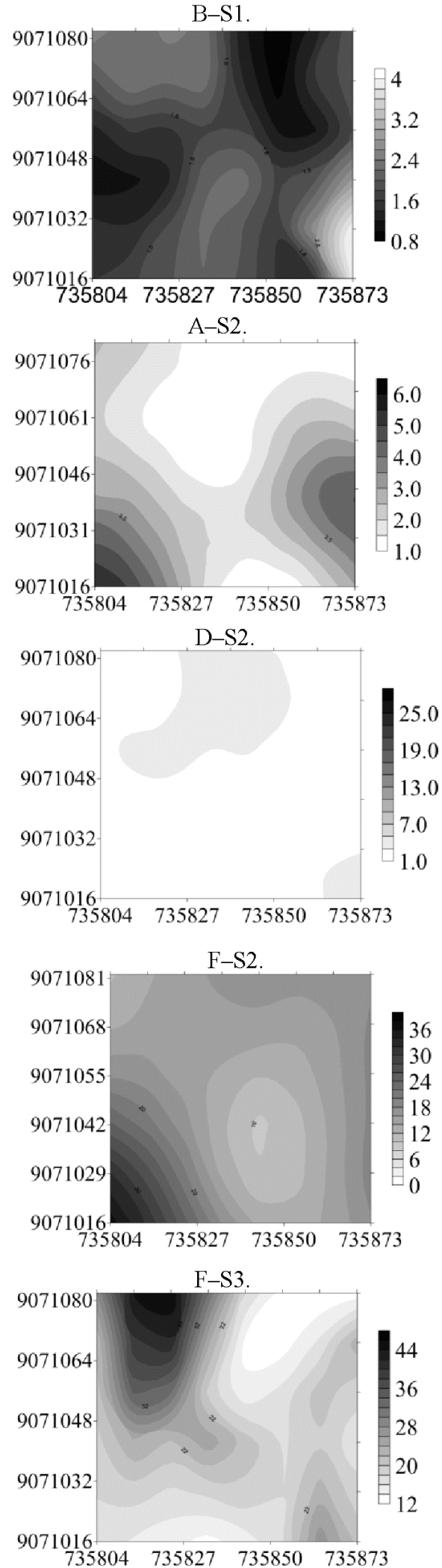
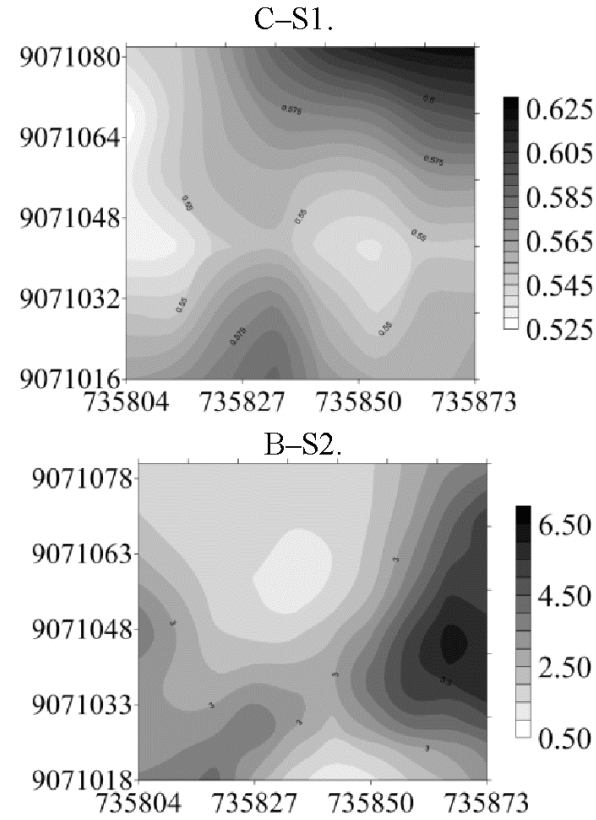

$\mathrm{G}-\mathrm{S} 2$.
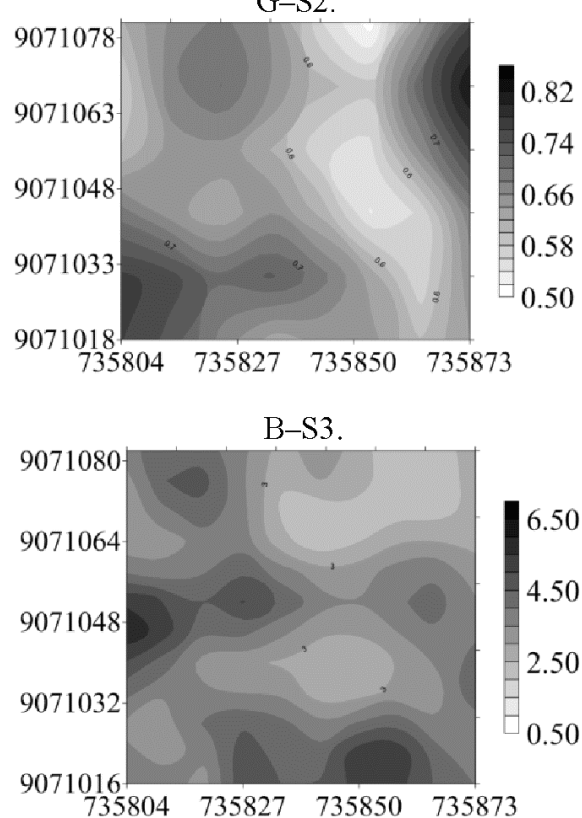

Figure 2. Isoline maps of Area 2 for the contents of calcium (A), magnesium (B), total nitrogen (C), sodium (D), potassium (E), $\mathrm{C}-\mathrm{CO}_{2}$ evolution rate $(\mathrm{F})$, organic carbon $(\mathrm{G})$ and $\mathrm{pH}(\mathrm{H})$ at six months $(\mathrm{S} 1)$ and after $90(\mathrm{~S} 2)$ and $180(\mathrm{~S} 3)$ days without neem cake 
The nearer lines showing narrower strips for this type of map characterize higher spatial variability, while wider strips present greater uniformity. Comparing the maps for each element, before and after application, there were a few similarities in the patterns of spatial distribution, indicating that the incorporation of neem cake must have influenced the dynamics of these nutrients in the treated area. The increase in the variability of $\mathrm{C}-\mathrm{CO}_{2}$ evolution rate due to neem cake incorporation possibly results from the influence of the organic matter on the different microbial communities (Gleixner, 2013). For OC (Figures 1F-C1, 1F-C2 and 1F-C3), neem cake application increased the variability and the contents in the soil, showing narrower lines at the end of the study. Menezes \& Silva (2008) reported similar behavior to the effects of organic fertilizers on soil fertility.

In the maps of samplings 1, 2 and 3 in Area 2 (Figure 2), there was no narrowing of the strips for any of the chemical variables over time, indicating that there were no great chemical alterations in the soil. The highest variabilities were observed for TN in samplings 1 and 2, OC in sampling 2 and $\mathrm{C}-\mathrm{CO}_{2}$ evolution rate in sampling 3 . The amount of carbon in the soil under cultivation systems is the response between the rates of residue addition, mineralization and humification.

Less aggressive and more efficient techniques in an integrated management system for guava are necessary, especially in the Brazilian Northeast region, where edaphoclimatic conditions are less favorable to the crop. The incorporation of neem cake as an alternative measure proved to be viable not only to improve soil quality, but also due to the need for a sustainable agriculture, with high yield, quality and low economic and environmental impact.

\section{Conclusion}

Neem cake incorporation promoted chemical alterations in the soil, increasing the spatial variability and the supply of organic carbon, nitrogen and soluble salts to plants.

\section{Literature Cited}

Araújo, E. L.; Ribeiro, J. C.; Chagas, M. C. M.; Dutra, V. S.; Silva, J. G. Moscas-das-frutas (Diptera: Tephritidae) em um pomar de goiabeira, no semiárido brasileiro. Revista Brasileira de Fruticultura, v.35, p.471-476, 2013. http://dx.doi.org/10.1590/ S0100-29452013000200016

Cambardella, C. A.; Moorman, T. B.; Novak, J. M.; Pakin, T. B.; Karlem, D. L.; Turco, R. F.; Konopa, A. A. Field scale variability of soil properties in Central Iowa soils. Soil Science Society of America Journal, v.58, p.1501-1511, 1994. http://dx.doi.org/10.2136/ sssaj1994.03615995005800050033x
Campos, B. M.; Viana, A. P.; Quintal, S. S. R.; Gonçalves, L. S. A.; Pessanha, P. G. O. Quantificação da divergência genética entre acessos de goiabeira por meio da estratégia WARD-MLM. Revista Brasileira de Fruticultura, v.35, p.571-578, 2013. http://dx.doi. org/10.1590/S0100-29452013000200028

Carrasco, P. C. Nugget effect, artificial or natural? The Journal of The Southern African Institute of Mining and Metallurgy, v.110, p.299-306, 2010.

Chaves, A.; Pedrosa, E. M. R.; Coelho, R. S. B.; Guimarães, L. M. P.; Maranhão, S. R. V. L.; Gama, M. A. S. Alternativas para o manejo integrado de fitonematoides em cana-de-açúcar. Revista Brasileira de Ciências Agrárias, v.7, p.73-80, 2012. http://dx.doi.org/10.5039/ agraria.v7ila1489

EMBRAPA - Empresa Brasileira de Pesquisa Agropecuária. Manual de análises químicas de solos, plantas e fertilizantes. Distrito Federal - Embrapa Solos, 2.ed. 2009. 623p.

Gleixner, G. Soil organic matter dynamics: A biological perspective derived from the use of compound-specific isotopes studies. Ecological Research, v.28, p.683-695, 2013. http://dx.doi. org/10.1007/s11284-012-1022-9

Leão, M. G. A.; Marques Júnior, J.; Souza, Z. M.; Siqueira, D. S.; Pereira, G. T. Terrain forms and spatial variability of soil properties in an area cultivated with citrus. Engenharia Agrícola, v.31, p.643-651, 2011. http://dx.doi.org/10.1590/S0100-69162011000400003

Martinez, S. S. O nim Azadirachta indica: Natureza, usos múltiplos, produção. Londrina: Instituto Agronômico do Paraná, 2002. 142p.

Menezes, R. S. C.; Silva, T. O. Mudanças na fertilidade de um noessolo regolítico após seis anos de adubação orgânica. Revista Brasileira de Engenharia Agrícola e Ambiental, v.12, p.251-257, 2008. http:// dx.doi.org/10.1590/S1415-43662008000300005

Natale, W.; Rozane, D. E.; Parent, L. E.; Parent, S. E. Acidez do solo e calagem em pomar de frutíferas tropicais. Revista Brasileira de Fruticultura, v.34, p.1294-1306, 2012. http://dx.doi.org/10.1590/ S0100-29452012000400041

Santos, K. S.; Montenegro, A. A. A.; Almeida, B. G.; Montenegro S. M. G. L.; Andrade, T. S.; Fontes Júnior, R. V. P. Variabilidade espacial de atributos físicos em solos de vale aluvial. Revista Brasileira de Engenharia Agrícola e Ambiental, v.16, p.828-835, 2012. http:// dx.doi.org/10.1590/S1415-43662012000800003

Soares, W. L.; Porto, M. F. S. Uso de agrotóxicos e impactos econômicos sobre a saúde. Revista de Saúde Pública, v.36, p.209-217, 2012. http://dx.doi.org/10.1590/S0034-89102012005000006

Souza, Z. M.; Marques Júnior, J.; Pereira, G. T.; Moreira, L. F. Variabilidade espacial do $\mathrm{pH}, \mathrm{Ca}, \mathrm{Mg}$ e V\% do solo em diferentes formas do relevo sob cultivo de cana-de-açúcar. Ciência Rural, v.34, p.1763-1771, 2004. http://dx.doi.org/10.1590/S010384782004000600015

Warrick, A.W.; Nielsen, D. R. Spatial variability of soil physical properties in the field. In: Hillel, D. Application of soils physics. New York: Academic Press, 1980. p.319-344. http://dx.doi. org/10.1016/b978-0-12-348580-9.50018-3 